\title{
The sum of our parts: the voices of the Human Genre Project
}

Julia Boll

Department of Literature, Universität Konstanz, Konstanz, Germany

\begin{abstract}
The Human Genre Project is a website project launched in July 2009, inspired by and in response to the Human Genome Project, which collects writing in very short form. While the project evidently tries to 'humanize and/or translate science for a lay audience', it also attempts to give genetic research, which is often perceived as dehumanised, a 'face'. An attempt to respond to genetic research with a voice that can be identified as the voice of the object (become subject, perhaps) of scientific enquiry, the project counts as an example of the arts reaching out and pointing at the responsibility we have to recognise the Other not as the sum of their parts but as a subject in their own right.
\end{abstract}

\section{KEYWORDS}

Contemporary poetry; genetics research; public outreach; responsibility; two cultures

The Human Genre Project is a website project launched in July 2009, inspired by and in response to the Human Genome Project, the international scientific project that decoded the entire human DNA (completed in 2003). Conceived by Scottish science fiction writer Ken MacLeod, who at the time was writer in residence at the Genomics Forum, ${ }^{1}$ this project collects writing in very short form, 'short stories, flash fictions, reflections, poems, inspired by genes and genetics' (MacLeod, 2009-2013). Between 2009 and 2012, the Human Genre Project collected texts from over 50 authors.

Treating the Human Genre Project as a case study, the focus of this article is the acknowledgement and denial of humanity, the recognition of the object of scientific enquiry, and how literature interrogates these matters. Furthermore, I will examine how the discussion of ethical questions in literature on scientific themes presents itself not only as a portrait of the current state of affairs, but as an imagining of a potential state, to enable a broader understanding of the complex ethical responsibilities encountered by scientists, the sciences, and any society relying on scientific progress.

There are some 85 poems and about 20 prose texts collected on the website of the Human Genre Project, with some texts falling between the two forms. The homepage displays the 24 individual chromosomes - 22 pairs of autosomes and two sex chromosomes $^{2}$ - that make up the human genome, each depicted in a different colour. They function as tabs: by clicking on a chromosome it lights up, and, in the form of a drop-down menu, a list of titles and authors linked to the selected chromosome appears. These can then be accessed individually, leading away from the main site. 


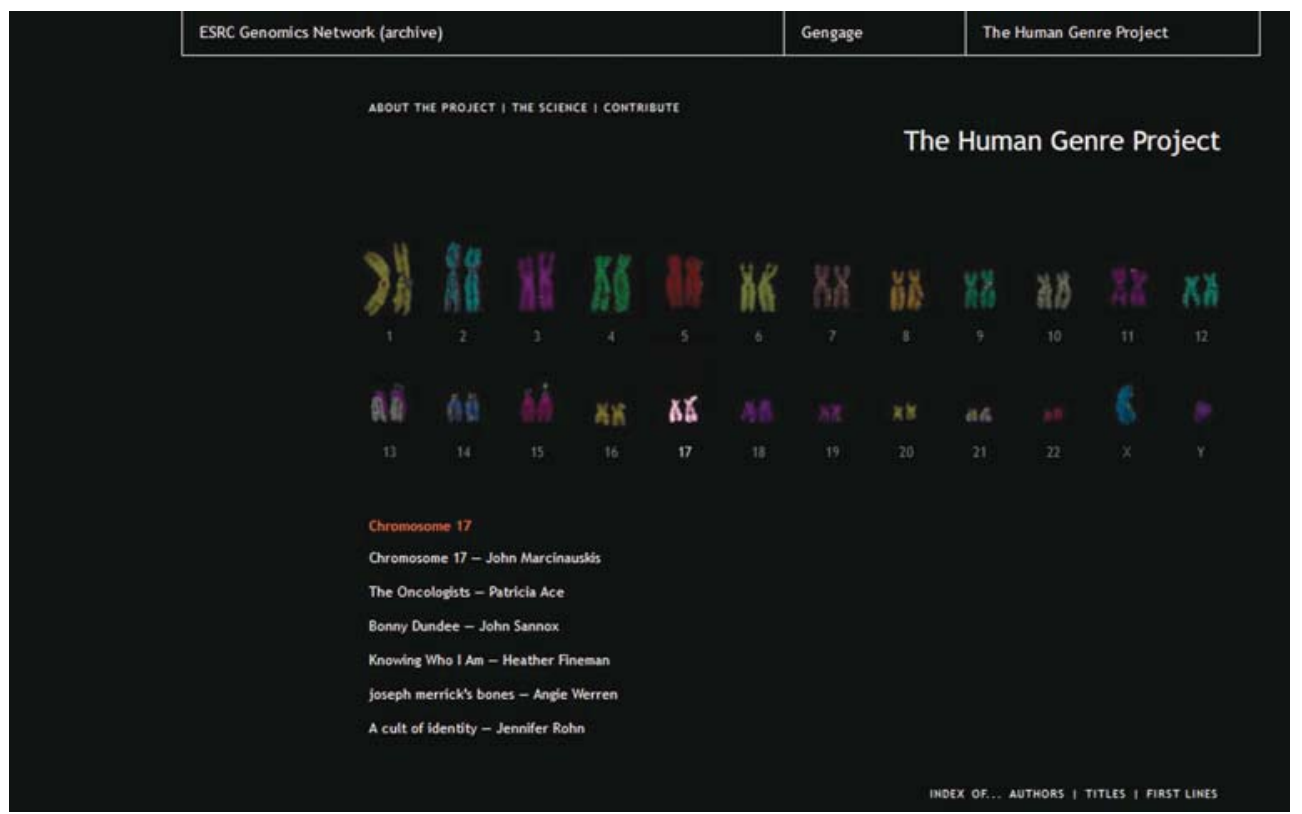

Figure 1. Chromosome 17 on the project's main site (<http://genomicsnetwork.ac.uk/humangenre project/index.php?id=17>).

For example, under chromosome 17, one of the works listed is Patricia Ace's 'The Oncologists'. The poem is a response to a painting by Ken Currie with the title 'Three Oncologists', which hangs in the Scottish National Portrait Gallery in Edinburgh. One of the doctors portrayed is Sir David P. Lane, who discovered the p53 gene, which sits on the short arm of chromosome 17 and is also known as 'the guardian of the genome' - its function contributing to preventing cells from turning malignant (Ace, 2009-2013). At the time of Ace's writing, the estimate was that one in three people in the UK would develop cancer in their lifetime. ${ }^{3}$

\section{Patricia Ace}

\section{The Oncologists}

Veiled in shafts of light,

harbingers of death or life,

the oncologists pause before

the theatre's dark curtains

like backstage actors,

shrouded in black.

\section{Surgical masks sag}

round their chins.

At the frontier of fear, experts in tumours, code, they have the faces of men who have seen it all.

These three spectral guardians, I hope I never meet them.

But I know the spiral helix, 
I know the one-in-three.

In its attempt to give genetic research a 'face', this poem - and the painting it references - relate to the subject this article intends to explore. Both Ace's text and Lane's painting portray a group of scientists whose knowledge very much attributes to them the role of 'harbingers of death or life', whose choices might well decide if someone lives or dies, whose research, however, has been guided by a sense of responsibility towards humanity.

Kelly Oliver draws on the work of Emmanuel Levinas and his notion of the 'face' as the factor enabling empathy with the Other in order to develop a theory of an ethics based on witnessing, on enabling the Other to form a subject identity not only by allowing for a voice, but by also witnessing the Other's act of speech. ${ }^{4}$ Levinas uses the term 'face' not in the sense of appearance, of facial features, but rather as the immediate expression of the Other in a direct encounter (the face-to-face relationship). He argues that ' $[t]$ he manifestation of the face is already discourse' (Levinas, 1969: 66), and that, in a rejection of Sartre's notion of the Other's objectifying, hostile gaze (cf. Sartre, 1992: 315-400), seeing the Other face-to-face does not actually constitute a distancing process, one that 'mistakenly puts the subject at the center of the universe' (Oliver, 2001: 204). Instead, it establishes an encounter of call and response. Reflecting on this face-toface encounter 'involves a calling into question of oneself, a critical attitude which is itself produced in face of the other and under his [sic] authority' (Levinas, 1969: 81). The face-to-face relation and the responsibility of the Self for the Other stands at the centre of Levinas' ethical philosophy: vulnerable and ultimately not visible in its entirety, the Other's face 'opens the primordial discourse whose first word is obligation' (201).

Oliver argues that there is an obligation to witness, to testify and listen to testimony, 'because subjectivity and humanity are the result of witnessing', from which she concludes that subjectivity and humanity may be regarded as the result of 'response-ability' (Oliver, 2001: 90). ${ }^{5}$ She proposes that accepting the Other's subjectivity, recognising the reality of others' experiences even if they are incomprehensible to us, might allow us to establish 'the conditions of address-ability and response-ability that make subjectivity and human experience possible and ultimately ethical' (106):

[T]his means that we must recognize that not everything that is real is recognizable to us. Acknowledging the realness of another's life is not judging its worth, or conferring respect, or understanding or recognizing it, but responding in a way that affirms response-ability. We are obligated to respond to what is beyond our comprehension, beyond recognition, because ethics is possible only beyond recognition.

(Oliver, 2001: 106)

Both Levinas and Oliver argue that to act according to ethical principles is an active choice: one chooses to take on responsibility for the Other; one chooses to respond to the Other (Levinas, 1998: 49; Oliver, 2001: 180-181). The texts collected on the site of the Human Genre Project recognise the scientist as a person and not as the sum of their work; they recognise the object of scientific study as a person with a subject identity and not merely the sum of their parts. They stress that scientific progress is not in fact a goal in itself, but that it should be defined by the necessity of taking on responsibility towards the Other. Many of the authors collected in the Human Genre Project imagine a voice for the object of scientific 
enquiry. In this way, several of the poems on the website can be regarded as lyric poetry, snapshots of often intensely private emotions such as the personal confrontation with the lingering fear of cancer in Ace's poem above. They demand the reader's address-ability by establishing a subjectivity that acknowledges its vulnerability in view of the ever more detailed information coming out of genetic and neuroscientific research.

This reluctance to separate scientific knowledge and research from the life lived, in fact the continuous insistence throughout the Human Genre Project to explore the sciences from a personal angle, speaks to Mary Midgley's call for an end to the atomising of knowledge. Midgley (in Midgley, 2001) discusses in detail the implications of the so-called gap between the two cultures - the sciences and the arts - and argues that an approach to knowledge that only considers life in a compartmentalised, an atomised, way does not only fail to acknowledge the interconnectedness of scientific and humanist approaches to knowledge formation, but might in fact be the source of what is commonly called an "anti-science" feeling'. This feeling, she maintains, is 'not usually an objection to the actual discovery of facts about the world', but instead 'a protest ... against the way of thinking which deliberately extends the impersonal, reductive, atomistic methods that are appropriate to physical science into social and psychological enquiries' (Midgley, 2001: 1-2). At the beginning of the twenty-first century and in the wake of the so-called 'science wars', she charges science with a 'strange, imperialistic, isolating ideology', which seems to hinder any connection between science and poetry (1). But Midgley does not lay the blame at the door of the sciences alone: the arts, she argues, also have habitually treated science as a 'separate domain, irrelevant to the arts', and she further maintains that this separation has 'often produced a strange kind of apartheid in the teaching of literature, a convention whereby important and powerful writings are ignored if their subject-matter concerns science, or even the physical world' (22).

The texts from the Human Genre Project point at an artistic community's active interest in the scientific research that led to the decoding of the human DNA, and in the impact this knowledge has had on human lives and human experience. A number of the texts relate to specific chromosomes and address genes located on these. In many cases, there is also an entry on the site explaining the function of the particular gene which inspired a poem, or the anomaly of a gene which leads to a specific disease featured in a poem. For example, Julian Derry's poem 'The Meme Gene' refers to the apparent correlation between the evolvement of a new variant, an allele, of the gene that encodes the protein ASPM (Abnormal Spindle-like, Microcephaly-associated, see note on Figure 2) and is located on chromosome 1, and the development of written language ('In evolving/ASPM swelled Hamlet to city'). But it also refers to the devastating diagnosis, in a pre-natal examination, of an ASPM defect, which is likely to result in microcephaly:

\author{
Julian Derry \\ The Meme Gene \\ In beginning, \\ weapons over-lorded dominion; \\ survival \\ cast kin species apart. \\ In reasoning, \\ brain size drove paths of intellect; \\ consciousness
}


accounted by Descartes.

In converging,

thoughts combined for tribal identity;

religions

formed more than their just parts.

In concurring,

settlements merged into conurbation;

society

pursues horse like a cart.

In outgrowing,

cultures rose up from the heathen;

memetics

compose sacred fine art.

In evolving,

ASPM swelled Hamlet to city;

alleles

scattered across world charts.

In copying,

mind bombs flatten natal expectancy;

microcephaly

crumples parental hearts.

Of course, in its title and form, Derry's poem also plays on Richard Dawkins' concept of 'memes' as the cultural equivalent to genes with respect to self-replication and mutation. ${ }^{6}$ The corresponding note below Derry's poem provides concise background information for the poem:

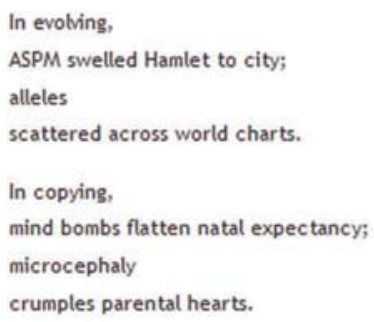

Defects in ASPM (Abnormal Spindle-like, Microcephaly-associated) lead to a

neurodevelopmental disorder in which the circumference of the head is more than two

standard deviations smaller than expected. Life expectancy for individuals is reduced and

the prognosis for normal brain function is poor. A new allele of ASPM appeared sometime

between 14,100 and 500 years ago with a mean estimate of 5,800 years ago which roughly

correlates with the development of written language, spread of agriculture and

development of cities.

- Julian Derny

PREVIOUS I CHROMOSOME 1 | NEXT

Figure 2. Detail of Julian Derry's 'The Meme Gene', including explanatory note (<http://genomicsnet work.ac.uk/humangenreproject/page.php?id=100>). 
Incidentally, these notes draw attention to the fact that the Human Genre Project is also an example of scientific outreach, for which the humanities are wont to be employed. As mentioned in the introduction to this article, the project was an initiative of the Genomics Policy and Research Forum funded by the UK's Economic and Social Research Council (ESRC), which had as its goal to 'ensure the visibility and use of the [ESRC Genomics] Network and its output' (Genomics Forum, 2013a). The overarching ESRC-funded Genomics Network initiative examined 'the social and economic implications of developments in the life sciences' (Genomics Forum, 2013a). Three of its four research centres continue to operate, but the Genomics Policy and Research Forum, which ran from 2004 to 2013 and was based at the University of Edinburgh, has ceased operation and today only exists in the form of an Internet archive. The writing project that became the Human Genre Project was one of a wide range of creative projects initiated by the ESRC Genomics Forum 'to engage audiences in debate around the life science[s]' and to interact within a wider scientific and public discourse (Genomics Forum, 2013a). In many displays of public outreach, the arts have been relegated to playing handmaiden to the sciences. Yet the diverse creative output stemming from the Genomics Policy and Research Forum can probably be cleared of the charge of merely engaging the arts in 'explaining the science' to a lay audience: apart from Ken MacLeod, creator of the Human Genre Project, the Forum lists several film makers, visual artists and photographers, fiction writers Pippa Goldschmidt and Ann Lingard, poet Samantha Walton and playwright Peter Arnott as resident and visiting artists contributing to their creative space (Genomics Forum, 2013b).

The texts collected on the website of the Human Genre Project are of varying literary quality and originality. What they have in common is a familiar, and yet wary, approach to the subject matter of genetics and to the body of knowledge and research associated with it. I would argue that the creative output on this site is evidence of a culturally and artistically educated and articulate stratum of society (likely predominantly Western, graduate, fairly homogenous Anglophone) that is quite at ease with knowledge of a double helix, the decoding of DNA, but which also harbours specific concerns and worries born from that particular level of informed-ness. The artists' at-ease-ness with the subject matter and the history of its representation in literature and art is particularly evident in those poems that draw on intertextual references to some of the staples of Western literature, such as user shardcore's concrete poem 'the telomeric tale of the mouse's tail', listed under chromosome $X$, and heavily referencing Lewis Carroll's concrete poem 'The Mouse's Tale' from his 1865 novel Alice's Adventures in Wonderland:

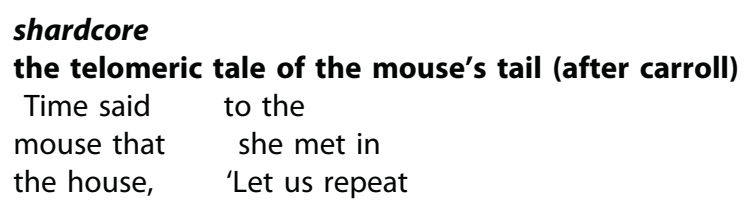




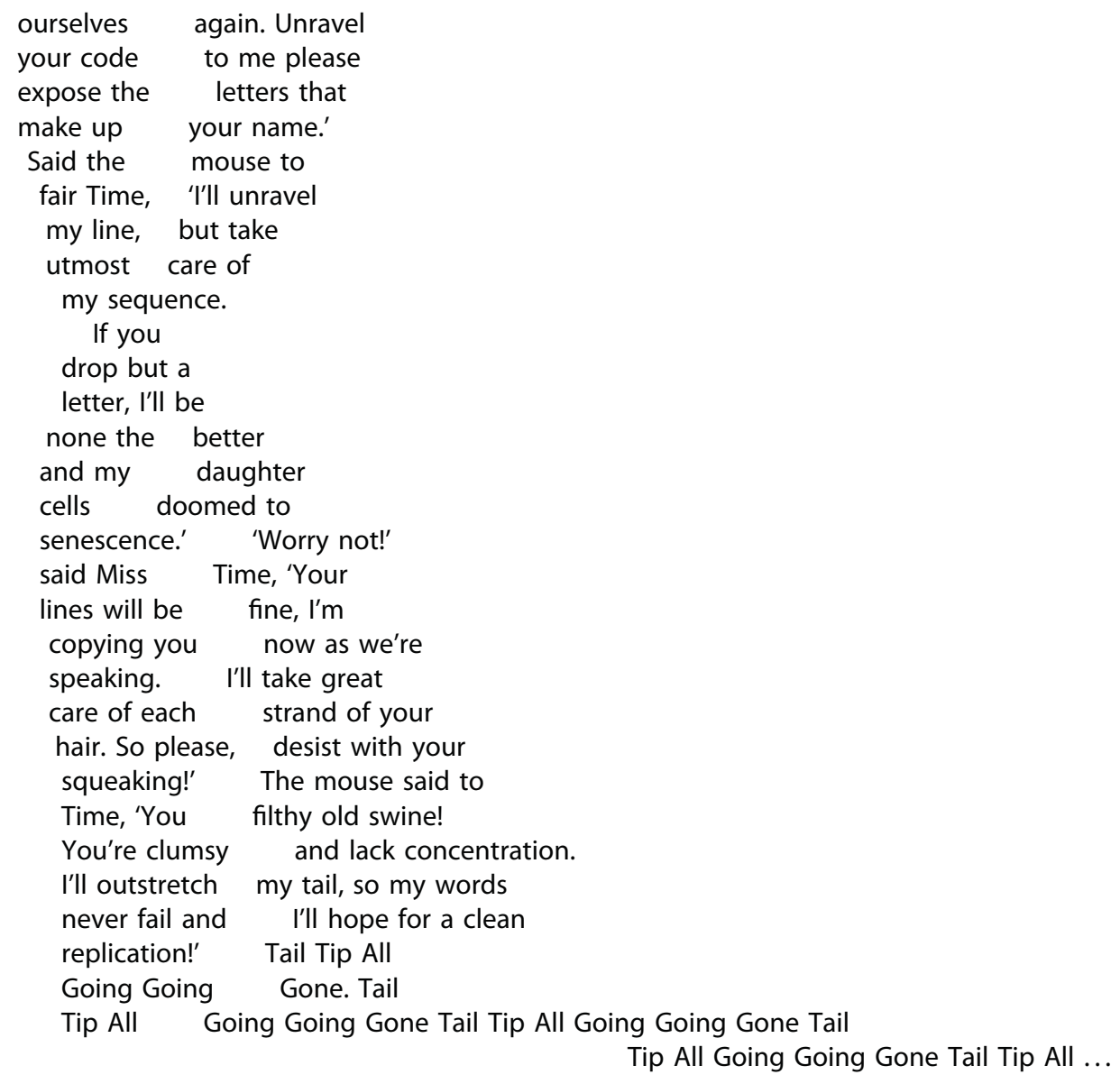

The telomere referenced in the title denotes the repetitive DNA sequence located at each end of a chromosome to protect it from damage. Arranged in the shape of a submetacentric chromosome and echoing Carroll's variation of the rime couée, this poem refers not only to the completed Human Genome Project, which has 'exposed the letters that make up' an organism's genetic material, but also to the process of regeneration through cell division and the potential danger of DNA damage during the replication process. A faulty replication - 'If you drop but a letter' - will eventually lead to cellular senescence, as cells will cease to divide. The mouse's lengthened tail doubles for the telomeres at both ends of a chromosome ('Tail' and 'Tip'), parts of which are permanently lost after each duplication ('Going Going Gone'), until the telomere is depleted and the chromosome stops regenerating for good. The telomeric coding sequence for vertebrae (humans and mice) is TTAGGG, indicated by shardcore's 'Tail Tip All Going Going Gone'. 


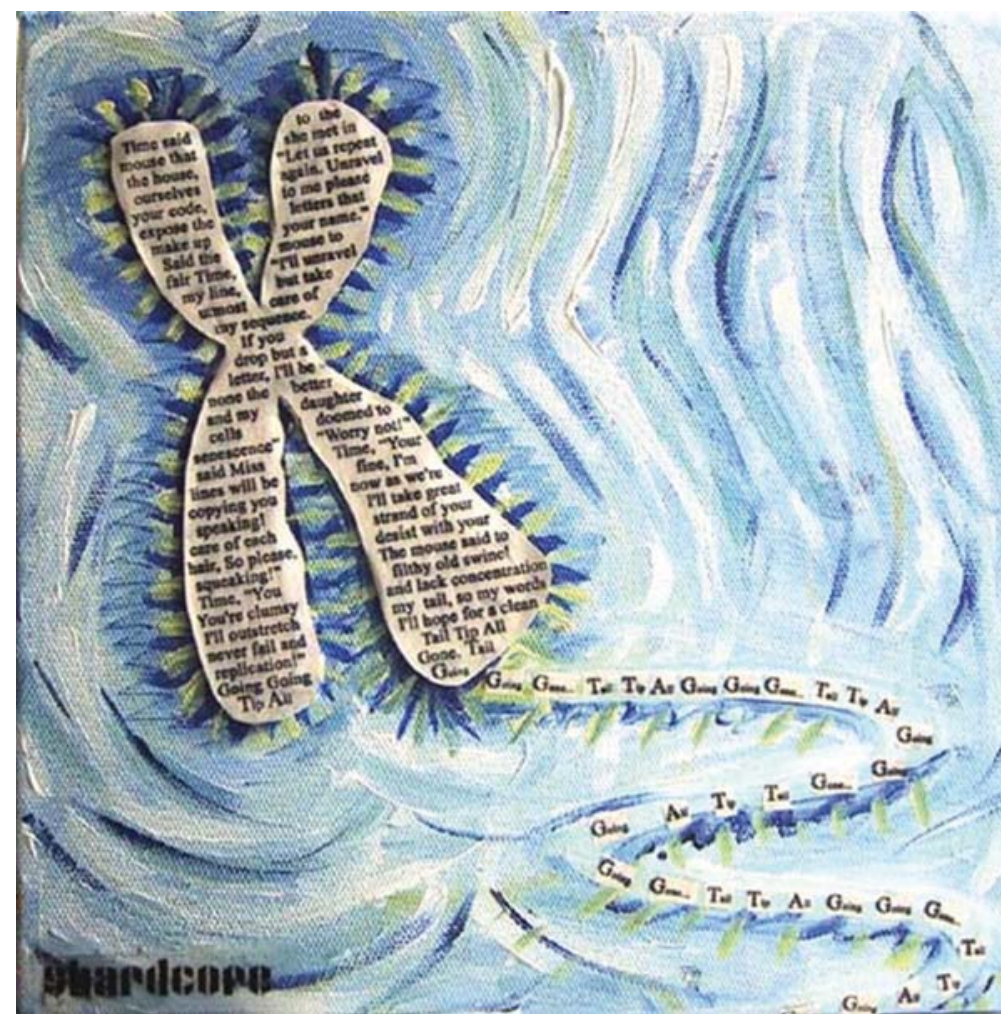

Figure 3. shardcore, 'the telomeric tale of the mouse's tail (after carroll)', archived at www.shardcore. org/shardpress/index.php/2005/07/03/the-telomeric-tale-of-the-mouses-tail-after-carroll-2005>.

The Human Genre Project is also an attempt to respond to genetic research with a voice that can be identified as the voice of the object (become subject, perhaps) of scientific enquiry. Amongst the texts grouped under chromosome 9, for example, the following poem can be found:

\author{
Francis Silva \\ Pseudoglyphs \\ So, \\ in an alphabet \\ of just five letters \\ and a grammar of three bonds \\ you can describe me \\ (and other beautiful people) \\ from birth to death. \\ Fine. \\ Now, \\ point me the text - \\ not the yarns that make me a body, \\ but the bits that make me a human.
}

The primness and guilelessness of this poem aside, it is an example of art reaching out, calling for something more than mere facts, pointing at the responsibility we have to 
recognise the Other not as their genetic make-up but, in fact, as a person, as a subject in their own right, with a voice. 'Pseudoglyphs' is written in the form of a direct address, calling for someone to witness this speech, to recognise the subjectivity and thus the humanity of the speaker by testifying to their voice, even if the observable code of their DNA sequence does not testify to individual subjectivity, even if having deciphered the 'glyphs' making up this body might give the impression that everything that is 'real' about it has been recognised already. The poem's confrontational approach once more evokes Midgley, who, in Are You an Illusion? (Midgley, 2014), cites Francis Crick, the molecular biologist and neuroscientist who co-discovered the structure of the DNA molecule with James Watson and who famously said:

You, your joys and sorrows, your memories and your ambitions, your sense of personal identity and your free-will, are in fact no more than the behaviour of a vast assembly of nerve-cells and their attendant molecules.

(Crick, 1994: 3)

To which Midgley shoots back that this particular brand of scientism shows that 'scientific doctrine is not meant to apply to the vulgar, common-sense world that we ordinary humans live in. Instead, it is intended to describe a separate, more refined, possibly Platonic world that only scientists can perceive' (Midgley, 2014: 150). This charge against gate-keeping and the exclusivity of scientific knowledge can be seen as developing from her earlier argument, expressed in Science and Poetry, that what is commonly called 'fear of science' is in fact grounded in

the fear that science may act as 'a materialistic, anti-human force' ... a natural response to certain powerful ideas which have long been associated with Western science because they were genuinely professed and linked with it by its earlier champions - ideas which are still influential and have not yet been explicitly enough disowned.

(Midgley, 2001: 49-50)

She argues that there is also a responsibility, on the side of the sciences, to 'acknowledge the influence that inhumane ideas have actually had on the scientific ethos and to get rid of them' (52). The Human Genre Project, as well as the other projects associated with the Genomics Forum, can be regarded as efforts to bridge this gap from both sides. Arguing that already the Romantic poets engaged in the effort to close the culture gap, Midgley maintains that Shelley's famous declaration that poets are 'the unacknowledged legislators of the world ${ }^{7}$ invites us to regard poets as

prophets, not in the sense of foretelling things, but of generating forceful visions. They express, not just feelings, but crucial ideas in a direct, concentrated form that precedes and makes possible their later articulation by the intellect and their influence on our actions.

(Midgley, 2001: 38)

This understanding of poetry as a 'concentrated form', which allows for the creation of powerful and immediate images, points at a possible reason why there are many more poems on the site than there are prose pieces - though the poetic genre is also specifically evoked by the visual set-up of the main site, where the chromosomes are 
set off starkly against an empty black space, like the complementary negative image of the white space around poems.

Midgley's call for the reciprocal recognition of the epistemologies of both the sciences and the arts with respect to their contribution to an interconnected formation of knowledge is also present in Simon Armitage's suggestion that poetry and science might have the same goal and try to achieve it by very similar means. 'This is what science does,' he writes,

like poetry, it deals in likeness, similitude, and equivalence. If you're gambling with the world and its actions, science gives you better odds, because its logic is linear, whereas the logic of poetry is radial, or at its very best, entirely spherical. Life, as we know, imitates art, and science, I believe, imitates life. I don't suggest that as a hierarchy of importance, but to reinforce the interconnectedness of the two disciplines through the intermediary of the human presence. ... Science didn't take man to the moon. It might have worked out the trigonometry, but it was a poetic dream that propelled us into the heavens to set foot on the lunar mass which has pushed and pulled at us from before we had eyes to see it.... Poetry proposed the existence of the DNA double helix with its eye for detail, and poetry postulated the theory of relativity with its penchant for cryptic crosswords, and poetry produced the first light bulb because of its fear of the dark, and poetry learned how to create fire from friction because of its grumbling dislike of the cold and its fascination with the supernatural effects of combustion.

(Armitage, 2006: 120)

The Human Genre Project is openly engaged in just such a reciprocal recognition between the natural sciences and poetry. The cautious tone of several individual texts notwithstanding, the project is not, in general, of a merely sceptic disposition, as already demonstrated above by shardcore's delightful tongue-in-cheek rendition of the mouse trying to protect her telomeres from time's aging process. An acute awareness, and at the same time a playful visualisation, of genes being split into coding and non-coding sequences can also be witnessed in Martin Maclnnes' poem 'Plans for Land', in which he speaks of "[s]warms of code. Curling " $\mathrm{C}$ "s stitched to/angular "T"s forming the net' (Maclnnes, 2009-2013). And on chromosome 3, we can find, in the concise form of Mark Stratton's poem 'Natural Cypher', the celebration of the sheer aesthetic beauty of the double helix:

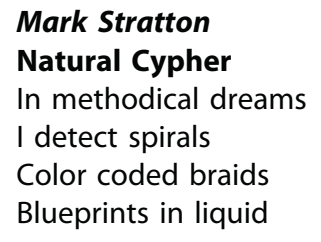

As introduced above, the Human Genre Project attempts to establish a link between the scientific endeavour of decoding the whole human genome and the human impulse to interpret it, as well as the effects this knowledge has had on humanity. Many of the poems touch on the ever-present fear of cancer, made more acute, perhaps, by a growing understanding of the many ways in which malignant cell growth can be triggered through genetic mutation. Elaine Westwick's poem 'SMAD4', which is situated on chromosome 18, imagines a deeply intimate and human moment concurring with 
the instant a genetic mutation is induced, causing the rapid growth of cancerous cells inside the speaker's body:

\title{
Elaine Westwick \\ SMAD4
}

I was making love at the time.

The slice of time when $G$ tripped to $A$

Deep inside,

Just once.

Silently.

The single A tottered and tipped the balance.

Go go go!

Grow grow grow!

As I slid and murmured the altered protein expressed Itself, folding into shape, caressing its partner.

Struggling here, slipping there.

The fit was gone!

The seed was sown.

Go go go.

Over the years my pancreas peddled the cycle of life Without brakes.

Gradually speeding up until I was overrun.

SMAD4 is a tumour suppressor gene on chromosome 18 involved in regulating the cell cycle. Mutations in this gene can cause unchecked cell growth and are present in $50 \%$ of pancreatic cancers.

To a certain extent, the project does 'humanise' science for a lay audience by means of intersemiotic translation. It also aims to give genetic research, often perceived as dehumanised, a 'face', which we could extend to Levinas' notion of the face: because these poems point at a state of vulnerability, as is evident from Westwick, who in the poem quoted above moves from an intimate moment of love-making to the body's complete take-over by malignant growth ('I was overrun'). A similar open exposure, tinged with hope and the unerring determination to develop, can be observed in Nick Wood's poem on fragile $X$ syndrome, a genetic condition causing developmental problems which usually affect males more severely than females:

\author{
Nick Wood \\ Fragile $\mathbf{X}$ \\ Lengthened gene on the short arm, \\ pulls the face and slows the brain; \\ knows neither culture nor class. \\ Short-sighted with gender, \\ but preferring males, the \\ unravelling DNA \\ measures out disability. \\ Still, despite all, on we go.
}

The texts of this project invite debate and call for a response while already responding to the science, and to the scientists involved. The Human Genre Project 
challenges the received notion of poetry as a private, personal genre that relies on a one-to-one relationship with the reader, a notion that stands in opposition to poetry's origins as an oral art, created within and for a community, and which has been countered by contemporary poetry's reclaiming of the public space in the form of performative poetry recitals and spoken word events. A collective endeavour, the visual set-up of the project already points to a community and a multiplicity of voices. The thematic interrelatedness of the different textual approaches, all of which refer to different parts of the human genome, clearly works as part of a whole and thus becomes a metaphor for the coding sequences of genes. This understanding of genetic research's contribution to an interdisciplinary, interconnected knowledge not only evokes Midgley's reading of poetry as visionary, in Shelley's sense, but also Oliver's suggestion to reconceive recognition from an understanding of the concept of vision 'that emphasises the ... connections - interdependence even - between the visible world and vision, between the seer and the seen' in order to move 'toward an acknowledgment of otherness' (Oliver, 2001: 221). Accepting that the gaps and spaces between different subjects 'open up the very possibility of communication and communion' (221), the Human Genre Project shows the arts reaching out towards the sciences, witnessing and responding and thus creating the possibility for both the sciences and arts to recognise each other.

For a contemporary literature examining the subject of science and ethics, there is a responsibility to not only portray what is, not even necessarily what should be, but much rather what could be, a responsibility to embrace the mood of the subjunctive. The present generation has a profound responsibility towards the future, towards imagining places, people, histories that are possible. There is an ethical responsibility to allow for voices outside the mainstream, and in this sense, literature, the arts, reach out and imagine realities where, often, we only see and appreciate describable facts.

\section{Notes}

1. This is short for the United Kingdom's Economic and Social Research Council's (ESRC) Genomics Policy and Research Forum, part of the ESRC Genomics Network, established in August 2004 and closed in 2013, when the Genomics Network ceased operation.

2. $X$ and $Y$, denoting this as a male genome.

3. In February 2015, Cancer Research UK updated this estimate to one in two (<http://www. cancerresearchuk.org/about-us/cancer-news/press-release/2015-02-04-1-in-2-people-in-theuk-will-get-cancer>).

4. Oliver mainly refers to Levinas' monographs, Levinas (1969) and Levinas (1998). See works cited.

5. There are links here to American poet Robert Duncan, who, already in 1960, defined responsibility as deliberately maintaining 'the ability to respond' (Duncan, 1969: 10).

6. Dawkins introduces the term in his 1976 publication The Selfish Gene.

7. From Percy Bysshe Shelley's 1821 essay 'A Defence of Poetry'.

\section{Disclosure statement}

No potential conflict of interest was reported by the author. 


\section{Notes on contributor}

Julia Boll holds a doctorate in drama from the University of Edinburgh. She was a director of the Scottish Universities' International Summer School and worked for the Edinburgh Review. In 2013, she joined the University of Konstanz to research the representation of the bare life on stage, a project for which, as PI, she has received funding from the German Research Foundation. Since 2012, she has also been a member of the multi-disciplinary research project Fiction Meets Science (Univs. of Bremen and Oldenburg). Her monograph The New War Plays was published by Palgrave Macmillan in 2013.

\section{Bibliography}

Ace, Patricia (2009-2013). 'The Oncologists.' The Human Genre Project (Chromosome 17). ESRC Genomics Policy and Research Forum. 6 Sept. 2017. <http://genomicsnetwork.ac.uk/humangen reproject/page.php?id=38>.

Armitage, Simon (2006). 'Modelling the Universe: Poetry, Science, and the Art of Metaphor.' Contemporary Poetry and Contemporary Science. Ed. Robert Crawford. Oxford: Oxford UP. 11022.

Crick, Francis (1994). The Astonishing Hypothesis: The Scientific Search for the Soul. New York: Touchstone.

Dawkins, Richard (1976). The Selfish Gene. Oxford: Oxford UP.

Derry, Julian (2009-2013). 'The Meme Gene.' The Human Genre Project (Chromosome 1). ESRC Genomics Policy and Research Forum. 6 Sept. 2017. <http://genomicsnetwork.ac.uk/humangen reproject/page.php?id=100>.

Duncan, Robert (1969). 'The Law I Love Is a Major Mover.' The Opening of the Field. London: Jonathan Cape. 10.

Genomics Forum (2013a). ESRC Genomics Policy and Research Forum. 17 Sept. 2017. <http:// genomicsnetwork.ac.uk/forum/>.

Genomics Forum (2013b). 'Creative Space.' ESRC Genomics Policy and Research Forum. 17 Sept. 2017. <http://genomicsnetwork.ac.uk/forum/creative-space/>.

Levinas, Emmanuel (1969). Totality and Infinity: An Essay on Exteriority. [1961]. Trans. Alphonso Lingis. Pittsburgh: Duquesne UP.

Levinas, Emmanuel (1998). Otherwise than Being: Or beyond Essence. [1974]. Trans. Alphonso Lingis. Pittsburgh: Duquesne UP.

MacInnes, Martin (2009-2013). 'Plans for Land.' The Human Genre Project (Chromosome Y). ESRC Genomics Policy and Research Forum. 6 Sept. 2017. <http://genomicsnetwork.ac.uk/humangen reproject/page. php?id=85>.

MacLeod, Ken (2009-2013). The Human Genre Project. ESRC Genomics Policy and Research Forum. 6 Sept. 2017. <http://genomicsnetwork.ac.uk/humangenreproject/>.

Midgley, Mary (2001). Science and Poetry. London: Routledge.

Midgley, Mary (2014). Are You an Illusion? London and New York: Routledge.

Oliver, Kelly (2001). Witnessing: Beyond Recognition. Minneapolis: U of Minnesota P.

Sartre, Jean-Paul (1992). Being and Nothingness: An Essay on Phenomenological Ontology. [1943]. Trans. Hazel Barnes. New York: Washington Square Press.

shardcore (2009-2013) 'The Telomeric Tale of the Mouse's Tail (After Carroll).' The Human Genre Project (Chromosome X). ESRC Genomics Policy and Research Forum. 6 Sept. 2017. <http:// genomicsnetwork.ac.uk/humangenreproject/page.php?id=30>.

Silva, Francis (2009-2013). 'Pseudoglyphs.' The Human Genre Project (Chromosome 9). ESRC Genomics Policy and Research Forum. 6 Sept. 2017. <http://genomicsnetwork.ac.uk/humangen reproject/page.php?id=114>.

Stratton, Mark (2009-2013). 'Natural Cypher.' The Human Genre Project (Chromosome 3). ESRC Genomics Policy and Research Forum. 6 Sept. 2017. <http://genomicsnetwork.ac.uk/humangen reproject/page.php?id=83>. 
Westwick, Elaine (2009-2013). 'SMAD4.' The Human Genre Project (Chromosome 18). ESRC Genomics Policy and Research Forum. 6 Sept. 2017. <http://genomicsnetwork.ac.uk/humangen reproject/page.php?id=112>.

Wood, Nick (2009-2013). 'Fragile X.' The Human Genre Project (Chromosome X). ESRC Genomics Policy and Research Forum. 6 Sept. 2017. <http://genomicsnetwork.ac.uk/humangenreproject/ page.php?id=103>. 